\title{
DSpace@MIT
}

\author{
MIT Open Access Articles
}

Husband-Killer, Christian Heroine, Victim:

The Execution of Madame Tiquet, 1699

The MIT Faculty has made this article openly available. Please share how this access benefits you. Your story matters.

Citation: Ravel, J. “Husband-Killer, Christian Heroine, Victim: The Execution of Madame Tiquet, 1699." Seventeenth-Century French Studies Volume 32, Number 2(2010): 120-136.

As Published: http://dx.doi.org/10.1179/026510610X12857561930714

Publisher: Maney Publishing

Persistent URL: http://hdl.handle.net/1721.1/60918

Version: Author's final manuscript: final author's manuscript post peer review, without publisher's formatting or copy editing

Terms of use: Attribution-Noncommercial-Share Alike 3.0 Unported 


\section{HUSBAND-KILLER, CHRISTIAN HEROINE, VICTIM: THE EXECUTION OF MADAME TIQUET, 1699}

In spite of celebrated eighteenth-century writings by Cesare Beccaria, Voltaire, and other philosophes, public executions and state-sponsored torture continued well after 1800 in Europe and elsewhere. The last public guillotining in France, for example, took place in 1939, at a time when lynchings still happened regularly in the United States. Waterboarding and other American practices during the Iraq War remind us that twenty-

first century governments still condone physical torture. ${ }^{i}$ Any linear narrative, therefore, that equates legalized torture and public executions with an 'Old Regime', and their abolition with 'modernity', is based more on wish fulfillment than careful historical analysis. Both liberal notions of progress based in Enlightenment thought and Foucaultian accounts of ever-expanding micro-technologies of individualized control require greater nuance. ${ }^{\text {ii }}$ Furthermore, as historians influenced by anthropological studies of ritual have noted, the interpretation of acts of torture and public executions have proved notoriously difficult for governments to control. In the Early Modern period, state-sponsored rituals of torture and execution, intended either to deter would-be criminals or exact theological or jurisprudential revenge against the condemned, often went awry in practice. Stoic scaffold performances or botched executions by incompetent hangmen might lead those in attendance to sympathize with convicted individuals, rather than abhor them. The potential always existed for those present at executions to draw conclusions antithetical to the intentions of government ministers and penal theoreticians of Church and State. ${ }^{\text {iii }}$ 
Keeping these caveats in mind, I propose to analyze one seventeenth-century French case study, the 1699 trial and execution of Angélique-Nicole Carlier Tiquet on charges of mariticide. The Tiquet case was one of several notorious Old Regime affairs in which a woman was charged with the murder of her husband, or other close family members. Other examples include the cases of the Marquise de Brinvilliers in the 1670s, convicted of poisoning her father and two brothers to death; and Marie-Catherine Taperet, 'la veuve Lescombat', who planned the successful assassination of her husband on a Parisian street in 1755. In the same year that Madame Tiquet was convicted of mariticide, Marguerite Chauvelin, a provincial French commoner, narrowly avoided conviction for the same crime after an equally scandalous Parisian trial. ${ }^{\text {iv }}$ Each of these cases resonated beyond the courtroom because they challenged the assumptions of patriarchal authority fundamental to both the family unit and the absolutist monarchy during the Old Regime. They provoked fears that wives, mothers, and daughters, and royal subjects more generally, might resort to murder to overturn established social hierarchies. But they also prompted alternative interpretations of motives and outcomes, both during and after the closely watched trials and executions, which suggested a more diverse response to the verdicts. When analyzed carefully, these cases appear to have generated criticism of Old Regime judicial and penal standards, as well as approbation.

The Tiquet case is fascinating precisely because it defies us to place it as a fixed point on a timeline that leads to misleading modernist notions of progress and civility, or ever-expanding statist surveillance of citizens. During the two-month trial that followed the assassination attempt against her husband, official inquiry and public opinion coalesced around the idea that Madame Tiquet was guilty. At least some observers came 
to believe that her crime represented a threat to husbands and paternal authority more generally throughout the kingdom. In the wake of her torture and public execution, which she endured so gracefully that many observers found themselves lamenting her death, male Catholic polemicists argued in print about the meanings of her demise, while one female Protestant writer, Anne Marguerite Petit du Noyer, asserted her innocence. Several years later, in the 1702 edition of his Dictionnaire historique et critique, Pierre Bayle cited the case in the context of a broader secular reflection on marital relations in morally corrupt societies. These diverse literary assessments, expressed in several genres for differing audiences, testify to the multiple meanings contemporaries attributed to this troubling case.

Madame Tiquet, born Angélique-Nicole Carlier in 1657, was the daughter of an auditor who had been a clerk for the Minister of State Michel le Tellier in 1653. Previously, her father had been a bookseller in the town of Metz on the kingdom's eastern border. ${ }^{v}$ Her parents died when she was fifteen, reportedly leaving a million livres inheritance to be split between her and her brother. The young Angélique-Nicole, rich and beautiful, went to Paris, where she inevitably attracted many suitors. Among them was Claude Tiquet, a councilor at the Parlement of Paris, the highest court in the kingdom. Tiquet convinced Angélique-Nicole's aunt, a friend of his, that he enjoyed a large fortune. Angélique-Nicole, trusting her relative and dazzled by several extravagant 
gifts she received from Tiquet, accepted his marriage proposal. The couple were happy for a while, during which time Madame Tiquet gave birth to a daughter and a son.

But the young woman eventually realized that her husband had deceived her about the extent of his fortune. Rumors of her extra-marital affairs began to spread, perhaps linked in the public mind to her marital discontent. In particular, tales of Madame Tiquet's alleged dalliance with Gilbert Gaulmin de Montgeorges, a captain in the king's guards, circulated widely at court and in Paris. At the beginning of the 1690s her husband, upset by her alleged infidelities, was granted a lettre de cachet, a secret order from the King authorizing his wife's incarceration. This effort to lock up his wife failed, however; according to one report, when he showed his wife the order she tossed it in the fire, and the king's officials ridiculed him when he requested a replacement. ${ }^{\mathrm{vi}}$ Towards the end of the decade, Tiquet renewed his complaints to the king about his wife's liaison with Montgeorges, prompting the monarch to forbid his captain to see Madame Tiquet. One journalist claimed that Louis ordered Montgeorges to move out of the Parisian neighborhood inhabited by the unhappy couple. Meanwhile, Madame Tiquet obtained a legal separation of goods from her husband, to protect her inheritance. One observer reported that 'beaucoup de froideur' existed between them. ${ }^{\text {vii }}$

Their estrangement was thus well known when, around 10 PM on April 8, 1699, Monsieur Tiquet left the home of his relative Monsieur Vilmain, with whom he dined every evening. As he neared his residence Monsieur Tiquet was accosted by two men, one of whom snarled at him: 'Te voilà, il y a longtemps que je t'atens, il faut que tu meures'. He then fired two shots at him with a pistol, while the other assassin drew his sword and struck Tiquet several times. viii One of Vilmain's servants, who usually 
accompanied Monsieur Tiquet to his residence, ran back to inform his master of the assault. The wounded Tiquet was transported back to Vilmain's house, rather than to his own home; the police report hinted that the door to his townhouse was barred and he was refused entrance. When Madame Tiquet and her son went to see him later that evening, Vilmain did not allow them entry to the chamber where he lay, fearing that their unwelcome presence might hasten his death. Madame Tiquet apparently withdrew without insisting upon entering the room where her husband lay. Although he was seriously wounded, Tiquet's situation began to stabilize overnight. The next day, fully conscious, he filed a complaint with the neighborhood police commissioner, prompting the Paris Lieutenant General of Police to authorize an investigation into the incident. The testimony of Monsieur Tiquet, and that of his servants and other neighbors, quickly caused the police to settle on Madame Tiquet and her porter Moura (against whom Monsieur Tiquet had filed a grievance on a separate matter two days before) as the main authors of the plot against his life. ${ }^{\text {ix }}$ Four days later Madame Tiquet was arrested at home by the Lieutenant Criminal and a squadron of fifty men who led her away to the Petit Châtelet prison.

These events were widely noted in Paris and at Versailles. There were accounts of the assassination attempt in the court journals of the Marquis de Dangeau and the Marquis de Sourches the day after it took place, and another a week later in the Histoire journalière, a French-language newssheet from the Netherlands that appeared twice a week. The presence of these narratives so close in time to the assassination attempt suggests that the case immediately became news at court and in town. Contemporaries 
even reported hearing a popular song in the streets that made reference to the supposed uncontrollability of Madame Tiquet:

En vain on croit la réduire. Plaintes ne l'a font que rire, Et si l'on prétend gronder

On se fait assassiner. ${ }^{\mathrm{x}}$

The judges of the Parlement of Paris, where Monsieur Tiquet was a councilor, also reacted swiftly to the news. The day after the attempt, Sourches wrote that ' [1]a grand'chambre députa un conseiller, pour aller trouver Tiquet, et l'assurer, de la part du corps du parlement, qu'il n'avoit qu'à se mettre l'esprit en repos, que rien ne lui manqueroit, et qu'on poursuivroit vigoureusement son affaire'. Furthermore, the Marquis noted, 'on vit tout Paris aller chez lui savoir de ses nouvelles et lui offrir de l'argent'. xi Dangeau, in his entry the day after the attack, hastened to add that although Madame Tiquet was under suspicion, no one believed that her lover, the Captain Montgeorges, was complicitous in the terrible deeds. Two weeks later, Dangeau added that there were strong indications that led one to suspect the guilt of Madame Tiquet, but that 'heureusement' no evidence had surfaced against Montgeorges. ${ }^{\text {xii }}$ Taken together, these reports summarize the immediate aftermath of the event. The police moved quickly to arrest a beautiful, rich woman accused of cheating on her husband; the spouse was assured that he would be avenged and that he would not lack for money; and her lover the soldier was tentatively exonerated in the court of public opinion. At the same time, many in Paris amused themselves by discussing the case and singing vaudevilles that mocked the principal protagonists.

Dangeau, Sourches, and the Dutch journalists continued to record news about the case, some of it contradictory, in the following weeks. On May 5, about a month after 
the alleged assassination attempt, Sourches reported a rumor, unfounded, that the real assassin had been arrested in Tours. He noted the uncertainty among those who were following the case: 'l'on parloit si diversement des preuves que l'on avoit contre la femme de Tiquet, qu'on ne savoit pas encore à quoi se rapporter'. xiii But two days later, the Histoire journalière warned that the affair 'va fort mal', that the evidence against Madame Tiquet was mounting on a daily basis, and that she had been transferred to the Grand Châtelet prison and placed under a tighter guard. In spite of the efforts of Madame Tiquet to remind her interrogators of the unconfirmed accusations that had misled the court in several other recent, high profile cases, 'on ne voit nulle aparence qu'elle s'en puisse tirer à moins que $\mathrm{S}[\mathrm{a}] \mathrm{M}[\mathrm{ajesté}]$ lui fasse grace'. ${ }^{\text {xiv }}$ Two weeks later Sourches repeated a rumor 'très mal fondée' that Madame Tiquet had fallen ill after having attempted suicide by poisoning herself. ${ }^{\mathrm{xv}}$ At the same time, the Dutch newsletter announced that Monsieur Tiquet had filed suit against his wife for the crime of adultery, in order to 'empêcher la confisquation de son bien, en cas qu'elle soit convaincue de l'avoir voulu faire assassiné'. xvi

On June 4 the Châtelet, the municipal law court for the city of Paris, condemned Madame Tiquet to death by beheading. There are few surviving records of the police and judicial investigations into the case, and no transcriptions of the proceedings before the Châtelet judges. ${ }^{\text {xii }}$ The absence of the latter is not surprising, given that French law did not call for verbatim records of court proceedings, and judges were not required to author opinions justifying their decisions. But the verdict published that June specified that Angélique-Nicole Carlier and Jacques Moura, her porter, were guilty 'd'avoir de complot ensemble médité et concerté de faire assassiner ledit Sieur Tiquet; et pour parvenir audit 
assassinat, fourni à plusieurs fois différentes audit Cattelain [another domestic] les sommes de deniers mentionnées au Proces'... xviii This carefully worded verdict indicates that the court had not discovered sufficient cause to convict Carlier and her porter of the specific attempt on Claude Tiquet's life on April 8, 1699. Instead, the magistrates determined that there was adequate evidence linking them to repeated efforts to kill Monsieur Tiquet over an unspecified period of time. At least one contemporary thought the decision was based primarily on the questionable testimony of the domestic Cattelain; Madame Tiquet maintained her innocence in the affair until interrogation by torture on the last day of her life. ${ }^{\text {xix }}$

Contemporaries and subsequent commentators paused over this ambiguity, noting that the court had convicted the pair for actions taken on repeated occasions to finance an assassination, not the April 1699 act itself. By the end of the seventeenth century, the relevant French law codes could be interpreted to mean that tangible acts to initiate a murder conspiracy were punishable by death. The judges relied most notably on a royal ordinance promulgated in Blois in 1579 that was reconfirmed in the Criminal Code issued by Louis XIV in $1670 .{ }^{\mathrm{xx}}$ Even though these ordinances did not specifically target women who plotted against their husbands, one contemporary commentator sympathetic to the case of Madame Tiquet asserted that the magistrates had depended on the 'loi de Blois, qui condamne à mort toutes les Femmes qui ont machiné contre leurs Maris', to send Madame Tiquet to the scaffold. ${ }^{\mathrm{xxi}}$ In short, it appears Madame Tiquet was convicted because the judges determined she had more than once initiated plots to kill her husband, but not because they had sufficient evidence linking her directly to the April 8, 1699 attempt. 
Death sentences rendered by the Châtelet municipal court were automatically appealed, so Madame Tiquet and her porter were granted a stay until the case could be heard by the Parlement, the royal court of appeal for Paris. The day after the Châtelet verdict, Monsieur Tiquet went to Versailles accompanied by his dinner host Monsieur Vilmain and his children by Madame Tiquet. There, somewhat surprisingly, he threw himself at the feet of the king to demand pardon for the woman accused of having plotted to murder him. This was not the first time that someone implicated in the scandal had appealed to Louis XIV; towards the end of April, according to the Dutch journal, Captain Montgeorges had gone to see the king to complain that his enemies were circulating rumors of his involvement in the assassination attempt. The king apparently told him that the case was in the hands of the magistrates, and that he (the king) did not wish to get involved. ${ }^{\text {xxii }}$ A month later, when the allegedly cuckolded husband appeared before him, the monarch was just as equivocal. Louis XIV received Tiquet and his family with 'beaucoup de bonté', and praised him for trying to save his wife. But Louis refused to promise him anything. According to the Histoire journalière, the king responded that 'il est bien genereux à vous de faire ce que vous faites; nous y songerons'. xxiii Sourches mentioned that the king promised to do 'tout ce qu'il pourroit pour lui faire plaisir' after the high court had rendered a verdict. ${ }^{\text {xxiv }}$ Angélique-Nicole's brother, who was a captain in the king's guards like Montgeorges, organized a final pardon effort. It was rumored that he had enlisted the aide of the Duchess of Burgundy, a royal favorite at court, to plead for Madame Tiquet's life. ${ }^{\mathrm{xx}}$ On the day of the execution, others whispered that if Madame Tiquet continued to insist on her innocence under torture, the king would pardon her. But none of these efforts succeeded. 
On June 17 the Parlement confirmed the lower court's death sentence for Madame Tiquet. When he heard of this judgment the next day, Monsieur Tiquet attempted to secure another audience with the king, but Louis made it clear he would not receive the distraught husband again. The chief justice in the Parlement suggested that Monsieur Tiquet retire to the countryside for a fortnight to avoid the public shame of execution, which he did. The couple's son decided to flee even further, crossing the Channel to England. The morning of June 19, now abandoned by her family, Madame Tiquet underwent interrogation by the judicial torturer. After being forced to swallow gallons of water and being threatened with more, or with blows to her painfully distended stomach, she 'confessed' everything, according to Sourches and the Dutch gazetteer. Yes, she had given twenty louis d'or to her porter to arrange the affair with a sergeant in Montgeorges' grenadier company; the sergeant called upon two of his nephews, as well as soldiers in the regiment, to carry out her wishes. Above all, according to the contemporary sources, Madame Tiquet insisted under torture that she had hidden her intrigue from her lover Montgeorges, 'parce qu'ils savoient bien que, s'ils lui en eussent découvert quelque chose, il n'auroit pas manqué de les en empêcher, étant trop honnête homme pour souffrir une affaire de cette nature'. Even though the crown was within its rights to seize the wealth of Angélique-Nicole, the king awarded the vast majority of it, more than one hundred twenty thousand livres, to Monsieur Tiquet and their children. ${ }^{\text {xxvi }}$ The crown also prohibited the post-execution publication of the Parlement's final verdict, in order to spare Monsieur Tiquet and his family further humiliation and ridicule.

A crowd assembled in the afternoon in the Place de Grève the afternoon of June 19 to witness the execution of Madame Tiquet. All the windows in the Hôtel de Ville, as 
well as those around the square and the streets leading into it, were filled with spectators of both sexes. ${ }^{\text {xxvii }}$ Madame Tiquet, dressed in white, arrived in a horse-drawn cart along with her porter Moura, also sentenced to die for his role in the plot. While stormy weather delayed their executions, Madame Tiquet regarded the crowd, the scaffold, and the executioner with tranquility. Finally, the rain and thunder dissipated, the ritual began. She watched with regret as Moura was hanged, then mounted the scaffold. She kissed her own hand, then extended it to the executioner in a gesture of forgiveness; her flawless demeanor reminded some onlookers of a virtuoso performance in a stage play. ${ }^{\text {xxviii }}$ She quickly tied her hair and moved it out of the executioner's way, then kneeled on the block. The nervous hangman, a substitute from the countryside who had never before beheaded a prisoner, failed at his first effort to decapitate her. He needed more than half a dozen swings of the axe to complete the job. The tens of thousands of people gathered in the square, horrified, let out a great cry, followed by a riot in which viewing stands collapsed, carriages were broken, horses injured, onlookers robbed, and, in several cases, people trampled to death. ${ }^{\text {xix }}$ In the midst of the tumult, his work finally finished, the hangman placed the severed head of Madame Tiquet on the edge of the scaffold looking towards the Hôtel de Ville, where it lifelessly presided over the chaos in the square. One female viewer was astonished by its beauty, even in death. ${ }^{\mathrm{xx}}$ Eventually, the head and the body were placed in a black-draped carriage that transported the remains to SaintSulpice, her parish church, for burial. Monsieur Tiquet, concerned for his wife's soul but perhaps as well for his public reputation, sent a donation with a request that forty masses be said for her. ${ }^{\text {xxi }}$ 
In the end, what can one conclude from these events that preoccupied Versailles, Paris, and a francophone public beyond the kingdom's borders for more than two months in 1699? The case began with the disastrous union between Monsieur and Madame Tiquet, an Old Regime marriage that could not be undone because the Catholic Church did not permit divorce. Thanks to the work of Sarah Hanley, Sarah Maza, Lynn Hunt, and many other historians, we know that the paternal authority of the state was in theory recreated in miniature in each French marriage. ${ }^{x x x i i}$ In the minds of many observers, marital discord prefigured, or mimicked, the instability of the State. A similar set of concerns were at play in the Pivardière affair, a murder case also being tried before the Parlement in the spring and summer of $1699 .{ }^{\text {xxxiii }}$ In this affair, the husband, Louis de la Pivardière, had bigamously married a second wife while away at war. When his first wife, Marguerite Chauvelin, found out, the two quarreled at their estate and the husband mysteriously disappeared; soon thereafter, the wife and her alleged lover the local prior were charged with conspiracy to assassinate the wayward husband. In this instance, after the dramatic appearance of a man who claimed to be the murdered husband, and after extensive judicial investigation, the wife was exonerated. The two cases were similar in that the evidence against both wives accused of plotting spousal homicide was shaky; the outcome of the Pivardière affair demonstrates that the system did not always decide against the accused woman. But the Dutch journalists and other observers following the affair were equally uncertain of the outcome. Their doubts suggest that traditional notions of honor and reputation were changing rapidly in France at the end of the seventeenth century, and that neither the law nor public opinion had fully absorbed these changes. The posthumous debate over Madame Tiquet's fate revealed the ambiguities 
sensed by observers over the two months from the assassination attempt to her public execution.

The Pivardière affair faded from public consciousness once the Parlement issued its final verdict in July 1699. Interest in the Tiquet affair, however, survived the court's judgment, in part because of the shocking spectacle of Madame Tiquet's public beheading. The trial and execution had raised questions about Madame Tiquet's motivations and morals that would not go away. As soon as the carriage carrying her body and severed head left the Place de Grève, onlookers began to fashion a narrative of her execution that emphasized her stoicism in the face of death. The next day, for example, Sourches remarked that 'elle alla à la mort avec une fermeté surprenante'. xxiv One month later, a Dutch Huguenot review edited by Nicholas de Gueudeville underlined two themes in its summary of the affair: 'la generosité du Mari, et la constance de la femme' ${ }^{\text {xxv }}$ Gueudeville was particularly astonished by Madame Tiquet's tranquility on the scaffold, which led him to conclude: 'je croi que s'étant tournée serieusement du côté de Dieu, quand elle vit que le Monde ne vouloit plus d'elle, la Réligion ne lui inspiroit plus que de beaux mouvemens, et elle s'étant détachée de la vie, à mesure qu'elle voyait avancer la mort, elle s'étoit rendue celle-ci familiere, \& elle s'étoit façonnée peu à peu à regarder comme un passage heureux' ${ }^{\text {xxxvi }}$ These remarks began an effort to convert the final travails of Madame Tiquet from vengeful justice to a symbolic spiritual triumph. 
This transformation continued in a published pamphlet entitled Oraison funèbre de Madame Tiquet, authored by the Abbot François Gastaud. ${ }^{\text {xxxvii }}$ The funeral oration was a fairly common literary genre at the end of the seventeenth century; JacquesBénigne Bossuet, among others, pronounced many of them at Versailles upon the deaths of illustrious male and female courtiers. Gastaud chose to write in this genre to "praise" the disgraced Madame Tiquet, an inversion that provoked François Gayot de Pitaval, writing a generation later, to label this particular oration 'moitié Panégyrique, moitié Satyre'. ${ }^{x x v i i i}$ In his text, Gastaud endowed Madame Tiquet with a greatness of spirit that manifested itself in her excesses: 'Angélique Carlier n'étoit pas faite pour les conduittes ordinaires, et que soit vice, soit vertu dans elle, tout devoit être marqué à un caractere de grandeur qui lui fut propre'. xxxix Her infidelities shocked her contemporaries to such an extent that they were seen as 'payennes', according to Gastaud, who compared Madame Tiquet to ancient female exemplars who exhibited 'traits de libertinage, d'infamie, \& de honte'. Nevertheless, he wrote, the soul of Madame Tiquet was never lost, because she had such 'grandeur'. ${ }^{x 1}$ In death, her spiritual greatness triumphed over her sinful tendencies.

The day of her execution, Gastaud wrote, an astonishing conversion took place over the course of six hours, only slightly more time than the authors of the French classical stage needed to provoke catharsis in their audiences. Her stoicism, and her civilities on the scaffold, indicate how far she had transcended the behavior of ordinary people: 'les autres criminals, en avouant leurs crimes font connoître toute la bassesse de leurs coeurs ; Angelique Carlier, dans l'aveu qu'elle fait de son crime, montre toute la grandeur de son ame'.... ${ }^{\text {xli }}$ After a life of debauchery, according to Gastaud, on the 
scaffold her actions and her countenance showed a moral fortitude, a simplicity, and a tranquility that had been suppressed by her wicked past, but that now re-emerged. Witnesses watching her were overcome with pity: 'on oublie ses fautes, on ne pense qu'à sa fermeté, et touché de cet air modeste, et paisible avec lequel elle envisage la mort, on ne peut résoudre à la voir mourrir'. ${ }^{\text {xlii }}$ In his text, Gastaud transformed her into a Christian heroine, a superhuman figure who benefited from the humiliation of the execution ritual to rise above her errors. ${ }^{\text {xlii }}$ This rewriting of her trial moved the affair beyond the themes evoked earlier of paternal authority, guilty military officers, or a corrupt magistrature.

Not everyone wanted to indulge in the apotheosis of Madame Tiquet, however. Gastaud's oration received a firm print rebuttal from Father Chaussemer, a monk and Sorbonne doctor, who was incensed that Gastaud thought a six-hour act of repentance on the way to the scaffold made up for a lifetime of debauchery. Far from a funeral oration designed to praise her, Chaussemer argued that Madame Tiquet's demise cried out for a sober discussion 'plein de bonnes et sages réflexions' on the events that led to her downfall. The resulting Discours moral et chrétien sur la vie et la mort de Madame Tiquet, addressed to an imaginary female acquaintance who had supposedly requested Chaussemer's thoughts on Gastaud's Oraison funèbre, emphasized one point above all others. ${ }^{\text {xliv }}$ The death of Madame Tiquet should not elevate the souls of onlookers through her stoic performance on the scaffold. Instead, it should inspire fear of God's inscrutable ways and humiliation before his divine will. Her performance in the face of death demonstrated her pride, insolence, and ostentation, not her Christian heroism; Chaussemer doubted that she even died a Christian, given her lifetime of wickedness. 
Worldly French sinners might learn from the mistakes she made while alive, but they should not be misled by an appearance of false nobility in the shadow of the executioner.

Gastaud, or someone writing in his name, responded to Chaussemer's charges in the Lettre à Madame de P., a pamphlet also published in $1699 .^{\text {xlv }}$ In it, the author admitted that his 'oraison' was in some sense an amusement, and he stated that he would never cite the example of Madame Tiquet to religious acolytes looking to him for spiritual guidance. ${ }^{\text {xlvi }}$ He nevertheless asserted that Madame Tiquet's evident grandeur on the scaffold made a philosophical point: the nobility of the human soul can manifest itself in the most unlikely of places, at the most unlikely of times. Theologians like Chaussemer who insisted on fear and humiliation as the only possible religious modality for a good Christian were as outdated as literary partisans who advocated the merits of the ancients over those of the moderns. Reason, not a mindless faith in Church authority, was the path to Christian salvation. Chaussemer's attempts to intimidate his readers, and his musty citations to scriptural authorities, reeked of a shopworn spirituality.

As if to confirm this point, another publication, entitled Le Triomphe de la Grace dans la conversion et la mort de Basilisse, appeared that year. It reprinted Gastaud's Oraison funèbre in between two poems further celebrating Madame Tiquet's Christian valor. ${ }^{\text {xlvii }}$ The first, entitled Basilisse dans sa prison, is a monologue in verse addressed to Jesus in which Madame Tiquet imagines her salvation while awaiting execution. As if responding to Chaussemer's attack on the sincerity of her repentance, this fictional Madame Tiquet bewails her past deeds and offers thanks for Christ's ultimate sacrifice on behalf of sinners like her. The endpoint of her earthly existence cannot come soon enough: 
J'attens la Justice Divine,

Puisque chaque instant m'achemine,

Au coup fatal qui va trencher leurs cours.

Je le verray partir sans en etre étonnée,

Il terminera mes douleurs,

Viens, favorable coup, vient finir mes malheurs

En finissant ma destinée.

This plaintive cry is followed in print by a second poem called L'Ombre de

Basilisse à son époux in which the shade of Madame Tiquet offers an apology to her

husband for the misery she has caused him. The blow that felled her was a pleasing one, because it reunited her with him in spirit as she was purged of her past infidelities. On the scaffold she found the secret to defeat infamy and resurrect her honor, and that of her husband:

A mon sexe il est du pour sauver son estime, A moi-meme, au public, aux Dieux, à mon Epoux, Graces au Ciel enfin je meurs quitte envers tous, Qui veut parler de moi se taise sur mon crime.

In other words, the fictional Angélique Carlier of the poem acknowledges the wrong she has done her husband, and offers the spectacle of her public death as compensation for her sins against patriarchal authority.

In death, therefore, the figure of Madame Tiquet acquired many uses for polemical writers. Not only did she offer an example of Christian repentance and heroism, as some spectators had perceived the day of the execution itself, but she also served as a talking point in the ongoing Catholic debates over the possibility of spiritual reform in this life. Her innermost thoughts in the hours leading up to her execution, and her most intimate communications with her spouse, were fictionalized and rendered public for readers avid to make sense of a case that some feared had been a miscarriage of justice. Others, unable to let go of the courageous image of her encounter with death 
on the scaffold, used the medium of print to provide a melodramatic reinterpretation of her final, seemingly heroic moments on earth. None of these polemicists questioned the judicial verdict, or regretted the torture inflicted on Madame Tiquet or the public spectacle of her execution.

While Madame Tiquet may have appeared to be a redeemed Christian heroine and exemplar of feminine devotion to some observers, others attempted to exonerate her. In her Lettres historiques et galantes, published in 1708, the Protestant writer Madame du Noyer included a narrative of the Tiquet affair written at the time of the trial and execution. $^{\text {xlviii }}$ In du Noyer's epistolary text, an anonymous correspondent describes events at court and in town to a friend in the countryside. The recital of the Tiquet affair occupies a central position in this correspondence in the spring and summer of 1699; du Noyer's interlocutor promises a detailed accounting of the gripping 'cause célèbre' for at least two letters before finally narrating the affair for her rural correspondent.

Far from being a fallen woman who found religion and sought her spouse's foregiveness at the last moment, the Madame Tiquet of the Lettres historiques is an innocent stoic sacrificed to the greed of her husband. The tale begins with an account of the difficult relations between the spouses, but Madame du Noyer's correspondent quickly moves on to an encounter between her, Madame Tiquet, and the Comtesse d'Aulnoy, a writer of fairy tales and other stories resident in Paris. During this exchange, which took place before the attack on Monsieur Tiquet, Madame Tiquet told her friends 
that a fortune-teller had recently predicted that within two months she would be 'audessus de mes ennemis, hors d'état de craindre leur malice, et parfaitement heureuse'. xlix In other words, like Gastaud, or the author of the posthumous verses that mouthed her final sentiments, du Noyer imagined a Madame Tiquet whose death would permit her to transcend her earthly woes. Unlike Gastaud, however, she does not assume Madame Tiquet's guilt, nor does she draw on the repertory of Christian shame and repentance to characterize her protagonist.

Du Noyer recounts the attack on Monsieur Tiquet, but she claims that he survived a wound near his heart because 'le coeur de Monsieur Tiquet fut en quelque maniere resserré par la peur, et ne remplit pas toute la place qu'il devoit naturellement occuper'. Her physiological and moral belittling of the legal councilor sets the tone for what follows. The day after the attack, while visiting her friend d'Aulnoy, Madame Tiquet claimed that even if her husband knew who had attacked him, he would not make an accusation, confident that public opinion would frame his spouse: 'c'est moi qu'on a assassiné aujourd'hui', the beleaguered wife told d'Aulnoy. ${ }^{\text {li }}$ Du Noyer claimed that some observers sympathetic to her cause made an effort to save Madame Tiquet before her arrest, but that Angélique-Nicole refused their help. Du Noyer thereby presented a counter-plot to the standard narrative characterizing Madame Tiquet as an unfaithful wife looking to rid herself of a burdensome partner. Instead, the Lettres historiques present an avaricious husband seeking to discredit his wife so that he could seize her inherited fortune. Once she had been arrested, du Noyer claimed, Madame Tiquet was convicted because she had allegedly conspired unsuccessfully to kill her husband three years earlier. Du Noyer emphasized that the investigating magistrates had not found any proof 
of Madame Tiquet's guilt in 1699. Furthermore, du Noyer reported that many people, including Madame Tiquet's brother, had urged her pardon: 'mais notre Archeveque representa au Roi, que s'il l'accordoit il n'y auroit plus aucun Mari qui fut en sureté' lii Against the machinations of her husband and the misogynist fears of the Archbishop and the King, Madame Tiquet had little chance, in spite of her declarations of innocence up to the day of her death.

'Ainsi fini la belle Madame Tiquet, qui avoit fait l'ornement de Paris; et quoi qu'on ne doive pas faire d'attention sur ce que disent les faiseurs d'horoscopes, il arriva pourtant à Madame Tiquet tout ce que la Devineresse lui avoit prédit, puisqu'avant deux mois elle se vit élévée sur un echaffaut et délivrée par sa mort de toutes ses peines' liii In this account Madame Tiquet also became a martyr. But instead of hailing her as a Christian heroine, du Noyer implies that she was sacrificed to the greed of her husband, and the cruelty and self-interest of men in power, especially the king and archbishop of Paris. Here, then, is a portrait quite different from that painted by the Abbot Gastaud in his Oraison funèbre. When we contrast the posthumous interpretations of the life of Madame Tiquet and her untimely death, we take stock of the full range of discourse about reputation and honor in France towards the end of the reign of Louis XIV. Before her death, observers most frequently cast Madame Tiquet as a supposedly unfaithful wife; this characterization contributed to her conviction and gruesome execution. Yet her stoicism in the face of an awful demise in turn encouraged polemicists to rehabilitate her posthumously as an exemplary Christian heroine. A rebuttal from a Sorbonne theologian only reinforced this heroic portrayal. Alongside the portraits of the debauched woman and the tragically noble condemned husband-killer, the literature of the Huguenot 
diaspora provided a third, feminist-inspired interpretation of the life and death of Madame Tiquet, one that argued she was sacrificed to the needs of French paternal authority. The many faces of Madame Tiquet found in the writings of her contemporaries alert us to the robust nature of public debate about honor, reputation, and morality in France circa 1700, and to the multiple, conflicting interpretations generated by judicial torture and state-run executions.

Given the interested commentary her life and death generated across the spectrum of Christian believers, it is perhaps not surprising to learn that Madame Tiquet inspired a footnote in the 1702 edition of Pierre Bayle's influential Dictionnaire historique et critique. ${ }^{\text {liv }}$ The article in which the reference appears, entitled 'Aegialia' ('Egialée' in French), is a critical examination of a tale from Ovid about the unfaithful wife of Diomedes. ${ }^{\text {Iv }}$ Venus, upset by Diomedes' actions at Troy, inspired an 'ardente lubricité' in his wife. She became attracted in particular to the man left behind as the steward of her husband's household, Cometes, whom Venus inflamed with a passion for Aegialia. In addition to their alliance, Ovid suggests that the couple planned to assassinate Diomedes upon his return from war. The author of The Metamorphoses seems to suggest that Diomedes barely avoided the trap they had laid for him, then quickly returned to Italy, although elsewhere Ovid claims that Diomedes may have gotten wind of the plot before his return, and never bothered to go home. The main text of Bayle's dictionary article summarizes the story as recounted by Ovid, but his extensive two-tiered footnotes, 
much longer than the précis of the classical narrative, take up the issue of women's marital infidelity. In particular, footnote 'E' asks the reader to consider the likelihood that the number of adulterous women who plot to kill their husbands is in fact a very small percentage of the total number of unfaithful wives. 'Ne m'allez point dire', Bayle writes, 'que les Gazettes...nous parlent souvent de certains Procès criminals intentez à des épouses dont les maris ont été tuez, ou l'ont pensé être'. The majority of husbands whose wives have cheated on them live tranquilly until natural death in old age separates them from their adulterous spouses. Furthermore, Bayle argues, husbands whose cheating wives plan murderous acts have been provoked to do so by their husbands' jealousy; these men have thrown up obstacles to their wives' freedom that in turn prompt the women to retaliate with murder or poison.

It is at this point in the footnote that Bayle brings up the Tiquet case. 'Gardezvous bien aussi de me citer Mr. Tiquet, si bon et si débonnaire', he writes. Yes, he pleaded with the king for his wife's life, but as far as Bayle is concerned, that does not prove that he gave her the freedom he should have before their marriage became a 'cause célèbre'. For Bayle the evils of spousal homicide, so potent for many contemporary readers and writers, take a back seat to the question of liberty within marriage, particularly once the issue is considered in an historical framework. Cato the Censor, Bayle notes, claimed that women in Antiquity who committed adultery were also necessarily poisoners. While this may have been true in Cato's day, Bayle concedes, it certainly did not hold true in later, more corrupt centuries, nor in Bayle's own time, when moral leniency had grown to levels unimaginable in Cato’s day. Infidelity, Bayle argues, is a necessary release in an age of corruption. Spousal promiscuity should be suffered 
with patience; if only Tiquet and other husbands displayed more tolerance for their wives's efforts to amuse themselves, Bayle suggests, the wayward spouses would eventually put down their poison, abandon their lovers, and return to their husbands' arms.

The method is distinctively that of Bayle and other early modern humanists and skeptics, who subjected classical texts to close, intensely critical readings. The sharp juxtaposition of Diomedes and Cato on the one hand, exemplary of the culture of classical antiquity, and Monsieur Tiquet on the other, torn from the newspaper headlines of the day, is typical of the intellectual ferment at the end of the seventeenth century. Not surprisingly, Bayle seems closest in sentiment to his Protestant co-religionist, Madame du Noyer, who found far more culpability in the actions of Monsieur Tiquet, Louis XIV and the Archbishop of Paris than in those of Angélique-Nicole Carlier. But whereas Madame du Noyer insisted on the innocence of Madame Tiquet in the specific context of her conviction and execution on charges of mariticide, Bayle weaves the case into a larger argument for the importance of personal liberty and toleration of individual actions and beliefs. To an early twenty-first century reader, Bayle might appear to be writing in a sarcastic vein. But as one of the most searching thinkers of his day, Bayle was quite earnest; marital infidelity, and fidelity, is a personal choice that should not be proscribed any more than an individual's decision to follow the religion of his or her choosing.

The passing reference to the Tiquet affair in the article 'Aegialia', published three years after the trial and execution that riveted Paris and the Court, rounds out contemporary interpretations of the case. Like Madame du Noyer and her followers, who held up the 'loi de Blois' as symbolic of French intolerance, misogyny, and tyranny 
towards the end of the Sun King's reign, Bayle seizes on the case to contest French political and moral orthodoxy. But he is ultimately more interested in critiquing inequalities within the institution of marriage than any of the other writers who comment specifically on the Tiquet affair. Bayle, and the secular, materialist thinkers who followed him in the eighteenth century, would have little need for Christian heroines, but they would seize eagerly on those whom they depicted as victims sacrificed to the inequities of Old Regime legal systems and social hierarchies. In this sense, Madame Tiquet might be construed as a forebear of Jean Calas, the unfortunate Toulousain Protestant whom the local Parlement wrongly accused of hanging his son when the latter allegedly threatened to convert to Catholicism. The texts of both Madame du Noyer and Bayle appear to prefigure Voltaire's successful efforts in the 1760s to rehabilitate Calas' reputation after his execution; the difference, one is tempted to argue, is that Voltaire had a greater genius for publicity, and the public opinion he so skillfully shaped carried more weight than at the end of the seventeenth century. ${ }^{\text {lvi }}$

It would not be wise, however, to insist on the writings of du Noyer and Bayle as predecessors of Voltaire's Traité sur la tolerance, and then dismiss the other accounts of the event as morally retrograde or barbarous. For one thing, Voltaire and other contemporary commentators on the Calas affair did not specifically cite these works, or any others produced during the Tiquet affair, during the 1760s. More importantly, while it is gratifying to early twenty-first-century humanitarian sensibilities to see the origins of our own revulsion towards torture and public execution in a subset of these late seventeenth-century writings, it is important to remember both the outcome of the trial, and the more widely disseminated 'Christian heroine' debate between Gastaud and 
Chaussemer. Few contemporaries were willing to consider du Noyer's claim that Madame Tiquet had been framed by her husband and a conniving paternalist state, particularly since it appeared in a revision of her clandestine publication that was not circulated until almost a decade after the death of Madame Tiquet. Bayle, who might have been in a position to play the posthumous advocate for her case that Voltaire adopted later in the Calas affair, relegated the case to a footnote. The obscurity of these two writings ca. 1700 is one of many arguments against an over-simplified reading of Old Regime public executions. A more nuanced interpretation of the Tiquet affair reminds us of the fallacy inherent in efforts to construct linear histories of such brutal public events that celebrate the supposed superiority of subsequent times and places. We should not assume that the battles joined by Madame du Noyer, or Pierre Bayle or Voltaire, are over. 


\section{ENDNOTES}

${ }^{\mathrm{i}}$ Clandestine film footage of the 1939 guillotining of Eugene Weidmann, which can be seen at http://www.youtube.com/watch?v=dXels5zsE_M, led to the end of public executions in France. On lynching in the US, see for example Michael J. Pfeifer, Rough Justice: Lynching and American Society, 1874-1947. Urbana: University of Illinois Press, 2004. On the United States' Department of Justice authorization of torture during the Iraq War, see David Cole, 'They Did Authorize Torture, but...', New York Review of Books, 8 April 2010, pp. 42-44.

${ }^{\text {ii }}$ For the origins of the 'liberal' argument, see Cesare, Marchese di Beccaria, On Crimes and Punishments, and Other Writings, ed. Richard Bellamy (Cambridge and New York: Cambridge University Press, 1995); Voltaire, Treatise on Tolerance, and Other Writings ed. Simon Harvey (Cambridge: Cambridge University Press, 2000); for the subtlycontrolling statist argument, see Michel Foucault, Discipline and Punish: The Borth of the Prison trans. Alan Sheridan (New York: Vintage Books, 1979).

iii Important works include Pieter Spierenberg, The Spectacle of Suffering. Executions and the Evolution of Repression: From a Pre-Industrial Metropolis to the European Experience (Cambridge: Cambridge University Press, 1984); Thomas Laqueur, 'Crowds, Carnival, and the State in English Executions, 1604-1868', in Lee Beier, David Cannadine, and James Rosenheim, eds., The First Modern Society: Essays in Honor of Lawrence Stone (Cambridge: Cambridge University Press, 1989), 305-55; Lisa Silverman, Tortured Subjects: Pain, Truth, and the Body in Early Modern France (Chicago and London: The University of Chicago Press, 2001; Paul Friedland, 'Beyond Deterence: Cadavres, Effigies, Animals, and the Logic of Deterence in Premodern France', Historical Reflections/Reflexions historiques 29 (Summer 2003), 259-317; Pascal Bastien, L'Exécution publique à Paris au XVIIle siècle: une histoire des rituels judiciaires (Seyssel: Champ Vallon, 2006); Lynn Hunt, Inventing Human Rights: A History (New York and London: Norton, 2007), pp. 70-112; Paul Friedland, Ritual, Spectacle, Extermination: The Evolution of Capital Punishment in Early Modern and Revolutionary France (forthcoming).

iv On the Marquise de Brinvilliers, see the summary in Lynn Wood Mollenauer, Strange Revelations: Magic, Poison, and Sacrilege in Louis XIV's France (University Park, PA: Pennsylvania State University Press, 2007), pp. 62-9, and the account by her confessor of her final hours in François Ravaisson, Archives de la Bastille (Paris: A. Durand et Pedone-Lauriel, 1870), t. 4, pp. 229-68; on Lescombat, Sabatine Juratic, 'Meurtrière de son mari: Un 'destin' criminel au XVIIIe siècle? L'Affaire Lescombat', Revue d'histoire moderne et contemporaine t. 34, no. 1 (Jan-March 1987): pp. 123-37; on Chauvelin, Jeffrey S. Ravel, The Would-Be Commoner: A Tale of Deception, Murder, and Justice in $17^{\text {th }}$-Century France (Boston: Houghton Mifflin, 2008). 
${ }^{\mathbf{v}}$ The sources on which I base my narrative of the affair include Bibliothèque nationale de France (herafter BnF) G 4287, Histoire Journalière, 1699; MM. Soulié, Dussieux, de Chennevières, Mantz, et de Montaiglon, eds., Journal du Marquis de Dangeau, publié en entier pour la première fois (Paris : Didot frères, 1856), VII : 61-2, 70-1, 93-4, 99-100 ; A. de Boislisle, ed., Mémoires de Saint-Simon (Paris: Hachette, 1888) Vol. 6, pp. 433-37; Gabriel-Jules, Comte de Cosnac and Edouard Pontal, eds. Mémoires du Marquis de Sourches sur le règne de Louis XIV (Paris: Hachette, 1886), vol. 6, pp. 144-67; Léon Lecestre, ed. Mémoires du Chevalier de Quincy (Paris : Renouard, 1898), I : 115-7 ; Nicolas de Gueudeville, L'Esprit des cours de l'Europe, où l'on voit tout ce qui s'y passe de plus important sur la Politique, \& en général ce qu'il y a de plus remarquables dans les nouvelles. Juillet 1699, pp. 155-67; Anne Marguerite Petit du Noyer, Lettres Historiques Et Galantes, De Deux Dames de condition, dont l'une est à Paris, \& l'autre en province. Ouvrage Curieux. Nouvelle édition, revue, corrigée, augmentée et enrichie des figures. Par Madame de C. (Amsterdam: Pierre Brunel,1720) Tome Premier, pp.189-91, 220-21, 230-31, 233-34, 238-48; and François Gayot de Pitaval, 'Madame Tiquet, condamnée pour avoir entrepris de faire assassiner M. Tiquet son mari' in Causes célèbres et intéressantes, avec les jugements qui les ont decidées (La Haye: Jean Néaulme, 1735) Vol 4, pp. 1-44.

vi 'Monsieur Tiquet... obtint une Lettre de Cachet du Roi pour la faire enfermer; mais il eut la faiblesse de donner cette Lettre de Cachet à sa Femme qui la jetta dans le feu; de sorte que lorsqu'il voulut en demander une autre, on se mocqua de lui', Madame du Noyer, Lettres historiques et galantes, p. 239.

${ }^{\text {vii }}$ Du Noyer, Lettres historiques et galantes, p. 239.

${ }^{\text {viii }}$ See Archives nationales (hereafter AN), Y11126, papiers du commissaire Eustache Claude de Berry, commissaire au châtelet de Paris, plainte pour Monsieur Tiquet contre le nommé Morel portier; 9 avril 1699.

ix Tiquet had accused the porter of illegally selling meat from his house; see AN Y11126. The porter's last name is variously rendered as 'Moura', 'Moras', and 'Morel' in the archival record. Here I have adopted the spelling found in the printed verdict of June 4, 1699.

${ }^{\mathrm{x}} B n F \mathrm{~ms}$ fr. 12643, f. 25. The songbook notes that this song was created 'dans le tems des avantures de Mrs. Tiquet et de La Pivardière'. On the songbooks, see Claude Grasland \& Annette Keilhauer, 'La Rage de Collection. Conditions, enjeux et significations de la formation des grands chansonniers satiriques et historiques à Paris au début du XVIIIe siècle (1710-1750)'. Revue d'histoire moderne et contemporaine 47-3 (juillet-septembre 2000) : 458-86; on popular song and political culture in the mideighteenth century, see Robert Darnton's 1999 Presidential Address to the American 
Historical Association, 'An Early Information Society: News and the Media in Eighteenth-Century Paris', at http://www.historians.org/info/aha_history/rdarnton.htm.

${ }^{\mathrm{xi}}$ Sourches, Mémoires, VI : 144.

xii Dangeau, Journal, VII: 61-2, 71.

xiii Sourches, Mémoires, VI: 150.

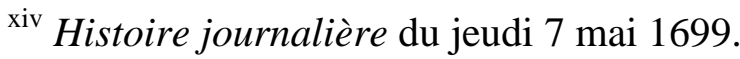

${ }^{\mathrm{xv}}$ Sourches, Mémoires, VI: 155.

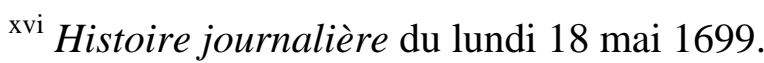

xvii In addition to the documents cited above at AN Y11126, see AN Y10018, 'Confrontation contre Augustin Cattelain' and 'Procès-verbal du question de Moura', 19 juin 1699.

xviii The arrêt is reproduced in François Gayot de Pitaval, Cause célèbres et intéressantes, avec les jugements qui les ont décidées (La Haye: Jean Neaulme, 1735), V: 13-16, quote at 14; a manuscript copy, with slightly different wording, can be found at BnF Z Thoisy 379 , fol. 44.

${ }^{x i x}$ Du Noyer, Lettres historiques et galantes, p. 243, suggests that Cattelain's testimony was decisive in the matter.

${ }^{\mathrm{xx}}$ See Gayot de Pitaval, Causes célèbres et intéressantes, V: 38-41.

${ }^{\text {xxi }}$ Du Noyer, Lettres historiques et galantes, p. 243.

xxii Ibid., du jeudi 30 avril 1699.

xxiii Ibid., du lundi 15 juin 1699.

${ }^{\text {xxiv }}$ Sourches, Mémoires, VI : 162.

${ }^{x x v}$ Du Noyer, p. 247; St-Simon, p. 435.

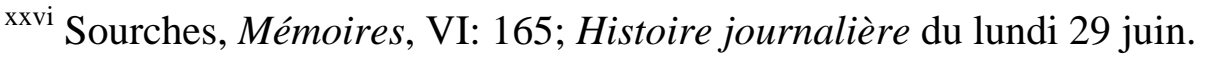

xxvii Saint-Simon (Paris : Hachette, 1888), VI :437. All the accounts of the execution agree on the size of the crowd and the passion of the spectators. De Sourches, for example, wrote: “...on ne sauroit s'imaginer quelle foule de monde il y avoit dans les 
rues pour les voir passer, et quelle effoyable multitude de peuple étoit dans la Grève, pour voir l'exécution. On avoit loué des fenêtres jusqu'à sept et huit pistoles. Et elles étoient remplies de personnes de la cour et de la robe, jusque-là on y voyoit plusieurs hommes et femmes qui avoient été longtemps en commerce avec la Dame Tiquet...," Sourches, VI :165. See also du Noyer Lettres Historiques Et Galantes, I :245 ; and Histoire journalière, 29 juin 1699.

${ }^{x x v i i i}$ Du Noyer Lettres historiques et galantes, I :246.

${ }^{\text {xxix }}$ Nouvelles extraordinaires (previously the Gazette d'Amsterdam), mardi, 30 juin 1699.

${ }^{\mathrm{xxx}}$ Du Noyer, Lettres historiques et galantes, I :248.

${ }^{\mathrm{xxxi}}$ Sourches, 165-6; Remarques historiques sur l'église et la paroisse de St Sulpice, extraites des instructions et priers à l'usage de ladite paroisse (Paris: Nicolas Crapart, 1773), p. 270.

${ }^{x x x i i}$ Sarah Hanley, 'Social Sites of Political Practice in France : Lawsuits, Civil Rights, and the Separation of Powers in Domestic and State Government, 1500-1800', American Historical Review 102 (1997), pp. 27-52 ; Sarah Maza, Private Lives and Public Affairs : The Causes célèbres of Prerevolutionary France (Berkeley : University of California Press, 1993) ; Lynn Hunt, The Family Romance of the French Revolution (Berkeley : University of California Press, 1992).

${ }^{x x x i i i}$ Ravel, The Would-Be Commoner, pp. 146-88.

${ }^{\text {xxxiv }}$ Sourches, Mémoires, VI : 165.

${ }^{\mathrm{xxxv}}$ Gueudeville, L'Esprit des cours..., p. 156.

xxxvi Ibid., p.162. One can also consult the Remarques historiques, op. cit.,published in 1773 but containing a narrative of the final hours Madame Tiquet. I have not been able to determine the origin of this text, which appears to have been written at the time of the execution of Madame Tiquet.

${ }^{x x x v i i}$ L'Oraison funèbre de Madame Tiquet (Cologne : Pierre L'Enclume, 1699). It is unknown whether Gastaud was a Jesuit, but if not he was certainly sympathetic to their theology. He was also a lawyer at the Parlement of Aix.

xxxviii Gayot de Pitaval, Causes célèbres, IV: 24.

xxxix Oraison funèbre, 9.

${ }^{\mathrm{xl}}$ Ibid., 8, 10, 14. 
${ }^{x l i}$ Ibid., 20-1.

xlii Ibid., 25-6.

xliii The Abbot Gastaud did not use the label 'Christian heroine' in the Funeral Oration, but it can be found in the Remarques historiques, p. 267, attributed to M. de la Chetardie, priest in the parish in which Madame Tiquet resided. Lettres historiques et galantes confirms that it was the parish priest who gave her this appellation.

xliv Chaussemer's original 1699 pamphlet is reprinted in full in Gayot de Pitaval, Causes célèbres et intéressantes, V: 333-52; quote above at p. 335.

${ }^{x l v}$ Reprinted in Gayot de Pitaval, Causes célèbres et intéressantes, V: 353-74.

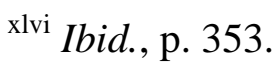

xlvii Le Triomphe de la Grace dans la conversion et la mort de Basilisse (1699). The nineteenth-century scholar Barbier attributed this work to Gastaud.

xlviii There are precise references to other events in 1699, and the factual details of the affair correspond to what one finds in Dangeau, Sourches, and the Dutch newssheets; see Madame du Noyer, Lettres Historiques Et Galantes. Anne Duggan, 'The Ticquet Affair as Recounted in Madame Dunoyer's Lettres Historiques et Galantes : The Defiant Galante Femme', Papers on French Seventeenth-Century Literature 24 (1997): 259-76, offers a critique of Madame du Noyer's narrative of the Tiquet Affair.

${ }^{\text {xlix }}$ Lettres historiques, p. 240.

${ }^{1}$ Ibid., p. 241.

${ }^{\text {li }}$ Lettres historiques, p. 241.

lii Ibid., p. 243.

liii Lettres historiques, pp. 247-8.

${ }^{\text {liv }}$ For an introduction to Bayle and the Dictionnaire historique et critique, see Richard H. Popkin, 'Introduction', in Pierre Bayle, Historical and Critical Dictionary. Selections ed. Richard H. Popkin, with the assistance of Craig Bush (Indianapolis: The Bobbs-Merrill Company, 1965), xi-xxxii; and, more recently, Jonathan Israel, Radical Enlightenment: Philosophy and the Making of Modernity 1650-1750 (Oxford: Oxford University Press, 2001), pp. 331-41. 
lv "Egialée," in Pierre Bayle, Dictionnaire historique et critique (1702?), 2:341-2; available online via ARTFL's Pierre Bayle Project at http://www.lib.uchicago.edu/efts/ARTFL/projects/bayle/

${ }^{\text {lvi }}$ A good recent narrative of the Calas Affair is Ian Davidson, Voltaire in Exile (New York: Grove Press, 2004), pp. 86-114. For a summary of the work inspired by Jurgen Habermas, The Structural Transformation of the Public Sphere: An Inquiry into a Category of Bourgeois Society trans. Thomas Burger (Cambridge Mass: MIT Press, 1989), see James van Horn Melton, The Rise of the Public in Enlightenment Europe (Cambridge: Cambridge University Press, 2001). 